\title{
Comparative Study and Characterization of Reduced Graphene Oxide (RGO) and Porous Reduced Graphene Oxide (P-RGO) Based on Coconut Shell Waste
}

\author{
Samnur $^{1}$, N. Azizah ${ }^{2}$, N. Fahira ${ }^{2}$, Zurnansyah ${ }^{2}$, Dirfan Zabrian², V. Zharvan², E.H. Sujiono2,** \\ 1 Department of Mechanical Engineering, Universitas Negeri Makassar, 90224 Makassar, Indonesia \\ ${ }^{2}$ Laboratory of Materials Physics, Department of Physics, Universitas Negeri Makassar, 90224 Makassar, Indonesia
}

(Received 16 October 2021; revised manuscript received 05 December 2021; published online 20 December 2021)

RGO and P-RGO samples based on coconut shell waste have been synthesized by exfoliation method. These samples were characterized using XRD, FTIR, and UV-Visible spectroscopy to obtain their crystal structure, functional group and optical properties. XRD results of the RGO and P-RGO samples show two peaks that are similar to those of RGO and P-RGO synthesized from pure (commercial) graphite. FTIR characterization of the RGO sample shows the hydroxyl $(-\mathrm{OH})$, aromatic $(-\mathrm{C}=\mathrm{C})$, epoxy $(\mathrm{C}-\mathrm{O})$ and alkoxy (C-O) functional groups at $3449.39,1627.63,1216.58$ and $1045.88 \mathrm{~cm}^{-1}$, respectively. Meanwhile, the P-RGO sample shows the hydroxyl $(-\mathrm{OH})$, aromatic $(\mathrm{C}=\mathrm{C})$ and epoxy $(\mathrm{CO})$ functional groups formed at $3450.51,1628.02$ and $1229.14 \mathrm{~cm}^{-1}$, respectively. In addition, UV-Visible results for RGO and P-RGO show sufficient optical performance. The band gap energy values of the samples obtained using the Tauc plot method are $3.50 \mathrm{eV}$ and $4.41 \mathrm{eV}$, indicating the semiconductor properties.

Keywords: RGO, P-RGO, GO, Graphite, Coconut shell waste, Band gap energy.

DOI: 10.21272/jnep.13(6).06017

PACS number: 81.05.uf

\section{INTRODUCTION}

The study of carbon materials is very interesting [1]. Among the various types of carbon, graphene is one of the most talked about materials in today's era. Graphene, a monolayer of $s p^{2}$-bonded carbon atoms [2], has generated wide scientific interest due to its unique properties [3]: excellent mechanical properties, very high electronic conductivity and very high thermal conductivity, and many other outstanding properties that made graphene an attractive material for various applications [4]. There are several main fabrication procedures of graphene, namely, peeling mechanics using the Scotch-tape method, epitaxial growth, chemical vapor deposition (CVD) [5]. Based on its characteristics, graphene has been widely used in the development of nanocomposite materials for different applications, such as supercapacitors, sensors, solar cells, and adsorbents [6]. However, graphene is still limited due to the high cost and low capacity of current production methods, so many researchers have tried to modify the structure of graphene and create a new type of graphene sheet structure, which is the so-called reduced graphene oxide (RGO) and porous reduced graphene oxide (P-RGO), that has the same properties and structure as graphene.

RGO is a carbon allotrope with a $2 \mathrm{D}$ network of $s p^{2}$ hybridized carbon atoms [7]. One of the current challenges is the development of a simple and efficient synthesis method for obtaining RGO required, namely the exfoliation method using ultrasonication [8]. Ultrasonication is a technology that utilizes ultrasonic waves for nanoparticles synthesized in recent years [9]. The ultrasonic process uses ultrasonic waves with high frequencies $>20 \mathrm{kHz}$, which convert electrical signals into physical vibrations that have a very strong effect on the solution, causing the breakdown of functional group bonds in GO [10].

P-RGO is a carbon material with pores [11]. Porous carbon materials are solids that have pores with a porosity of about 2-95\% [12]. Porous carbon materials play an important role because they have low density, high porosity, and the ability to bind to other atoms via hybrid orbitals such as $s p, s p^{2}$, and $s p^{3}$ [13]. P-RGO has various pore sizes, ranging from nano to macro size. According to the International Union of Pure and Applied Chemistry (IUPAC), pore size is divided into three types, namely macropores with a pore diameter greater than $50 \mathrm{~nm}(>50 \mathrm{~nm})$, mesopores with a pore size between $2-50 \mathrm{~nm}$, and micropores with a pore size smaller than $2 \mathrm{~nm}$ [14].

P-RGO is formed from GO with a loss of the oxygen functional group by means of a chemical method, it has the same characteristics as RGO in general, but it has pores [15]. The reduction of functional groups from GO to P-RGO changes its microstructure and physical properties similar to graphene [16]. In addition, P-RGO also has a high surface area, so it can be used as a supercapacitor, membrane for hydrogen gas separation, in lithium batteries and nanoelectronic devices [17].

This study uses naturally occurring graphite, namely coconut shell waste. Coconut shells are organic materials that can produce carbon elements after the heating process. After the heating process, the coconut shell will become coconut shell charcoal, which contains carbon (84.69\%), oxygen $(14.73 \%)$, and sulfur $(0.58 \%)$ [18]. Due to its high carbon content, it can be used as a base material for the synthesis of RGO and P-RGO. Furthermore, the sample will be characterized using XRay Diffraction (XRD), Fourier Transform InfraRed (FTIR), Scanning Electron Microscopy (SEM), and UVVisible spectroscopy.

\footnotetext{
*e.h.sujiono@unm.ac.id
} 


\section{EXPERIMENTAL}

\subsection{Synthesis of GO by Modified Hummers Method}

$1 \mathrm{~g}$ of graphite from coconut shell was mixed with $0.5 \mathrm{~g}$ of $\mathrm{NaNO}_{3}$ in $25 \mathrm{ml}$ of $\mathrm{H}_{2} \mathrm{SO}_{4}$, then stirred for $30 \mathrm{~min}$ in an ice bath. After that, $3 \mathrm{~g}$ of $\mathrm{KMnO}_{4}$ was slowly poured into the solution, while continuing to stir for $3 \mathrm{~h}$, in a temperature range of $20-0^{\circ} \mathrm{C}$, until the solution turned dark green. The solution was then removed from the ice bath and stirred for $1 \mathrm{~h}$. As much as $50 \mathrm{ml}$ of aquabides were gradually added and stirred for $1 \mathrm{~h}$. Then again $100 \mathrm{ml}$ of aquabides were added and stirred for $1 \mathrm{~h}$. To remove excess $\mathrm{KMnO}_{4}, 5 \mathrm{ml}$ of $\mathrm{H}_{2} \mathrm{O}_{2}$ were slowly added to the solution and stirred for $30 \mathrm{~min}$. The solution was then centrifuged at a speed of $3000 \mathrm{rpm}$ for $5 \mathrm{~min}$ to separate the sediment and liquid, then washed using aquabides until $\mathrm{pH} 7$ was obtained. After that, the samples were dried in an oven at a temperature of $110^{\circ} \mathrm{C}$ for $12 \mathrm{~h}$ to produce GO powder. The synthesis of GO by the modified Hummers method is a schematic exfoliation illustrated in Fig. 1.

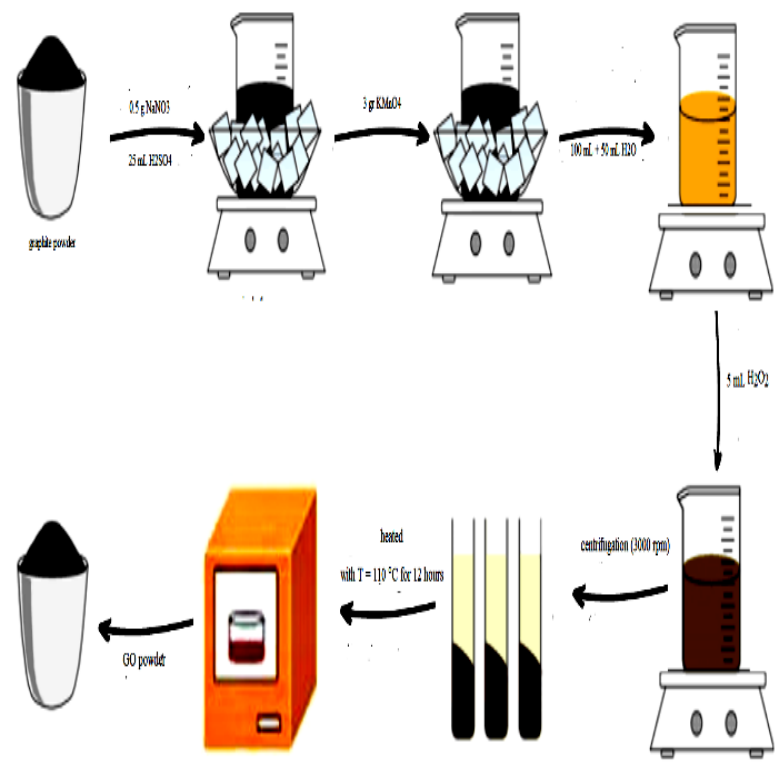

Fig. 1 - Schematic of GO synthesis by the modified Hummers method based on coconut shell waste

\subsection{Synthesis of RGO}

In this research, the RGO was synthesized by the exfoliation method using ultrasonication. $1 \mathrm{~g}$ of GO powder was mixed with $40 \mathrm{ml}$ of aquabides and then sonicated for $2 \mathrm{~h}$. After that, the solution was washed using aquabides until $\mathrm{pH} 7$ was achieved. The obtained precipitate was heated at $80^{\circ} \mathrm{C}$ for $6 \mathrm{~h}$ to produce RGO powder. The synthesis of the RGO by the exfoliation method is schematically illustrated in Fig. 2.

\subsection{Synthesis of P-RGO}

Ethylene glycol (EG) and water were mixed in a 1:2 ratio for $10 \mathrm{~min}$ at room temperature. The solution was then mixed with $1 \mathrm{~g}$ of $\mathrm{GO}$ and sonicated for $3 \mathrm{~h}$ (ultrasonic power $240 \mathrm{~W}$, ac voltage $220-240 \mathrm{~V}$ and frequency $40 \mathrm{kHz}$ ). The solution was re-centrifuged at $3000 \mathrm{rpm}$ for $15 \mathrm{~min}$ and then washed using aquabides until $\mathrm{pH} 7$ was obtained. After that, the samples were dried at a temperature of $80^{\circ} \mathrm{C}$ for $6 \mathrm{~h}$. The synthesis of P-RGO is illustrated in Fig. 3.

In the characterization process, an X-ray diffractometer (Shimadzu XRD 7000, $40 \mathrm{kV}, 30 \mathrm{~mA}$ ) and FTIR spectroscopy (Thermo Scientific Nicolet iS10) in the range $4000-500 \mathrm{~cm}^{-1}$ using $\mathrm{KBr}$ pellets were used to identify the crystal structure and functional groups. Optical characterization was carried out using UVVisible spectroscopy (Cary 50 UV-Vis Spectrophotometer from Agilent Technologies).
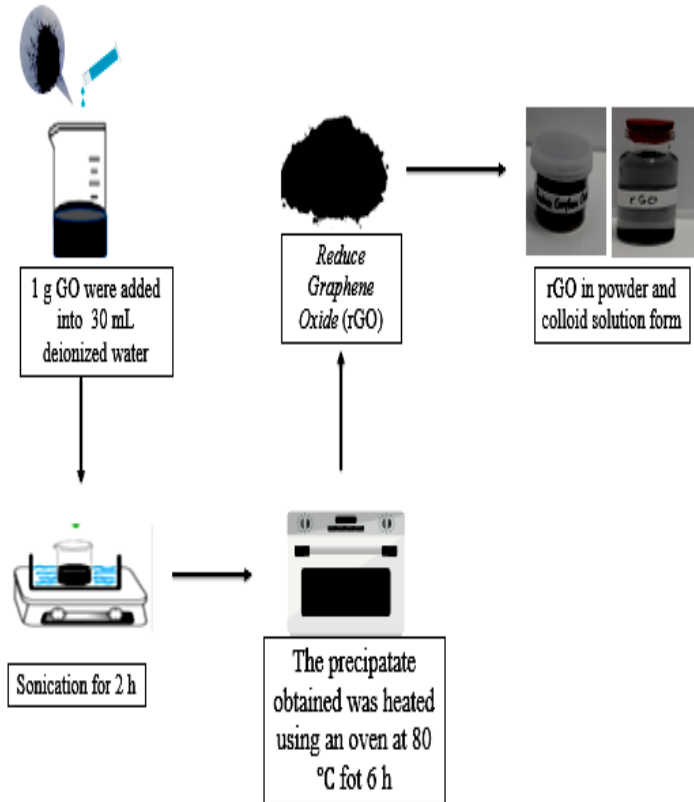

Fig. 2 - Schematic of RGO synthesis by the exfoliation method $\mathrm{H} 20: \mathrm{EG}-1: 2$

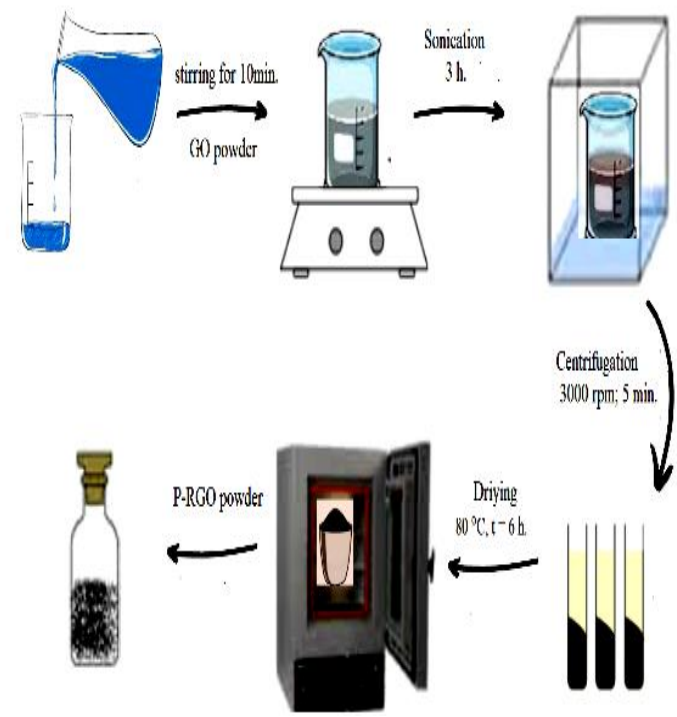

Fig. 3 - Schematic of P-RGO synthesis 


\section{RESULTS AND DISCUSSION}

The XRD characterization results for RGO and P-RGO are shown in Fig. 4a and Fig. 4b, respectively. The pattern shows an amorphous structure with two dominant peaks at $2 \theta$ angles of $23.23^{\circ}$ and $42.15^{\circ}$, while for the P-RGO sample, it shows two dominant peaks at $2 \theta=23.18^{\circ}$ and $2 \theta=42.96^{\circ}$. The pattern of the formed wide peaks indicates the presence of the P-RGO phase in the amorphous carbon graphite structure with reflections from the (002) plane [18]. This indicates that RGO and P-RGO phases have formed in the sample, which are similar to RGO synthesized from pure (commercial) graphite as a base material [19].
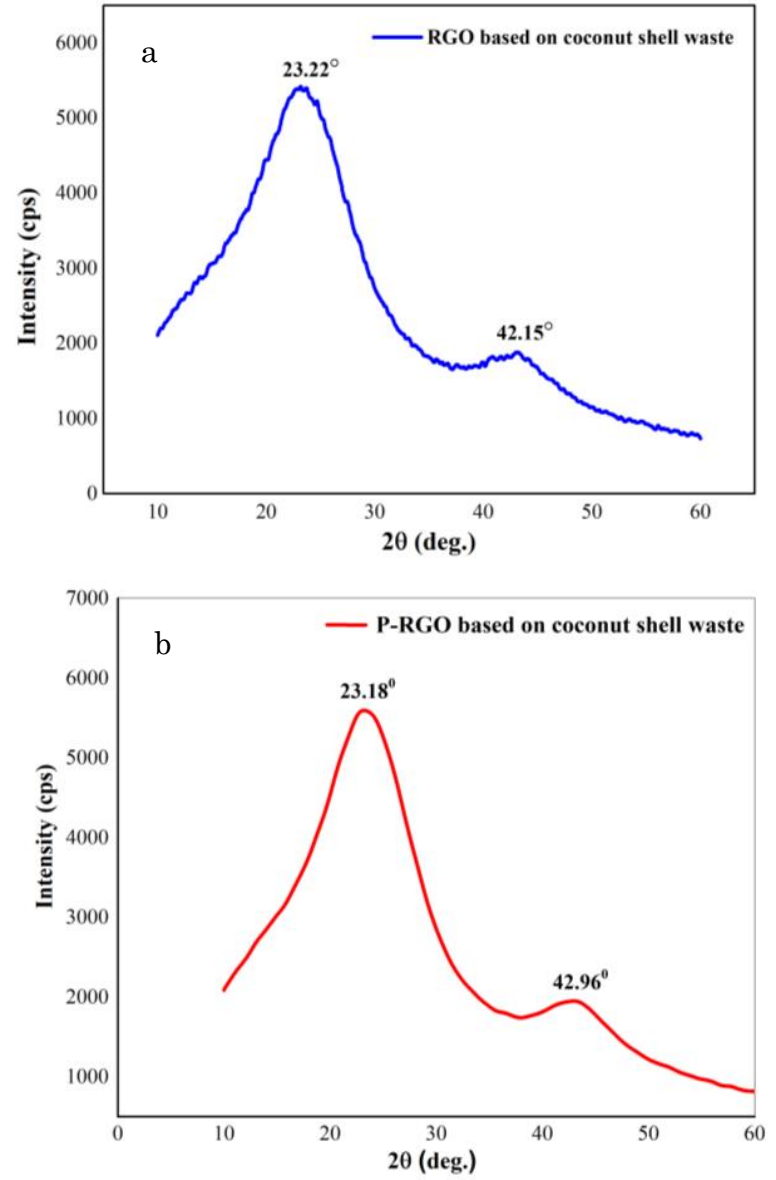

Fig. 4 - Diffraction patterns based on coconut shell waste: (a) RGO, (b) P-RGO

FTIR characterization was carried out to determine the types of functional group bonds in RGO and P-RGO made from coconut shell waste. Fig. 5 shows the FTIR spectrum of RGO and P-RGO samples obtained from coconut shell waste.

Fig. 5a illustrates the position of transmission peaks of RGO in the FTIR spectrum, indicating that functional groups have different binding energies. Stretching vibrations are observed from the following groups: hydroxyl $(-\mathrm{OH})$ formed at peak $1\left(3449.39 \mathrm{~cm}^{-1}\right)$, aromatic $(-\mathrm{C}=\mathrm{C})$ at peak $2\left(1627.63 \mathrm{~cm}^{-1}\right)$, epoxy $(-\mathrm{C}-\mathrm{O})$ at peak $3\left(1216.58 \mathrm{~cm}^{-1}\right)$ and alkoxy $(-\mathrm{C}-\mathrm{O})$ at peak 4 $\left(1045.88 \mathrm{~cm}^{-1}\right)$. The FTIR spectrum shows that the main groups belonging to RGO are identified, namely the functional groups $\mathrm{C}=\mathrm{C}$ and $\mathrm{O}-\mathrm{H}$. The two functional groups are bonded to each other and form the hexagonal structure of the carbon atom, which is located in the RGO layer. Peaks 3 and 4 show the presence of absorption bands resulting from $\mathrm{CO}$ vibrations, which are the residue of the carbonyl group during the reduction process [20].

Fig. 5b shows the results of FTIR characterization for P-RGO. As seen, there are peaks, which represent the hydroxyl compound functional group $(-\mathrm{OH})$ formed at peak 1 with a wavenumber of $3450.51 \mathrm{~cm}^{-1}$, the aromatic carbon functional group $(\mathrm{C}=\mathrm{C})$ formed at peak 2 with a wavenumber of $1628.02 \mathrm{~cm}^{-1}$, and the epoxy functional group $(-\mathrm{CO})$ formed at peak 3 with a wavenumber of $1229.14 \mathrm{~cm}^{-1}$. Comparison of the functional groups data can be seen in Table 1 .
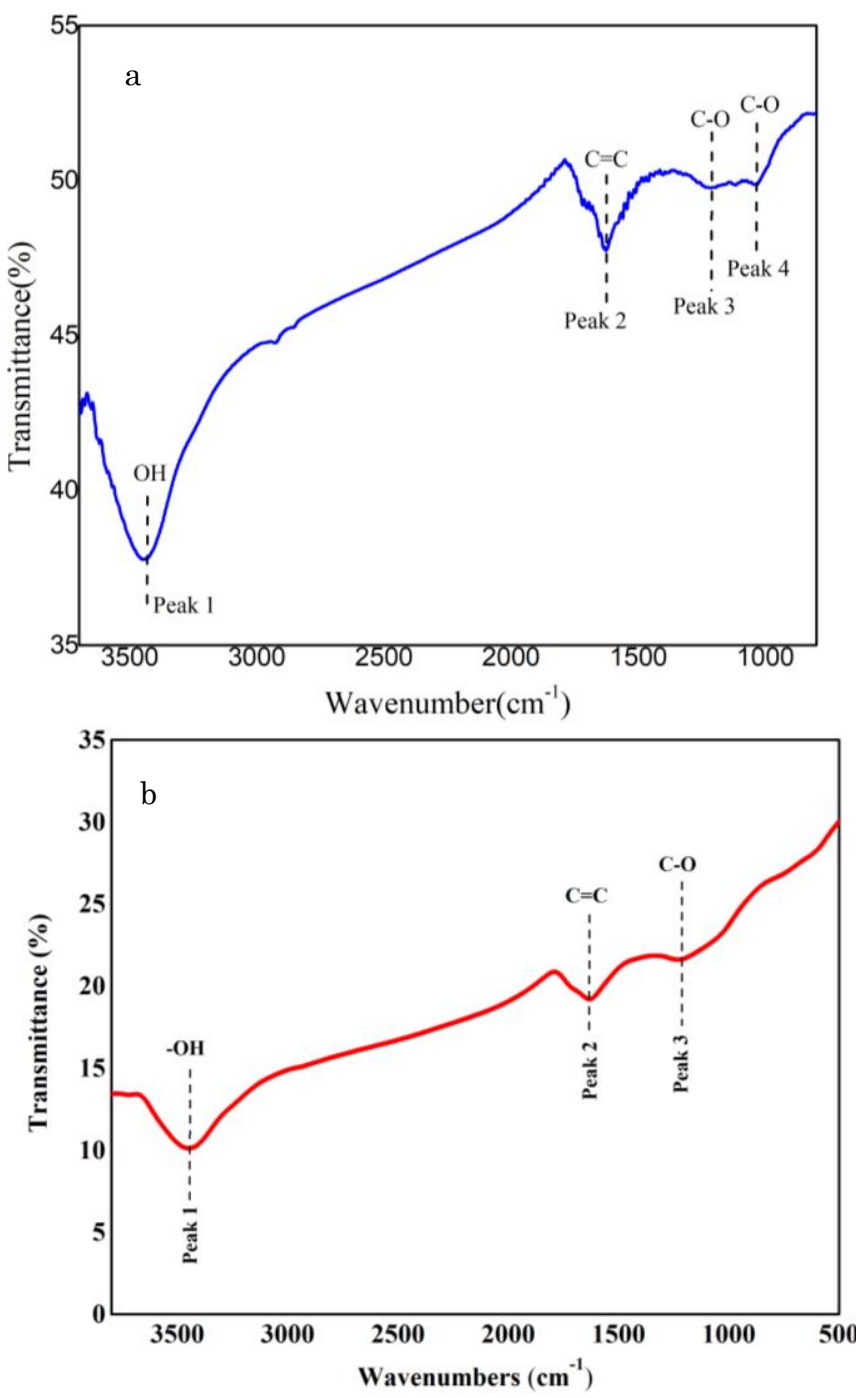

Fig. 5 - FTIR spectrum based on coconut shell waste: (a) RGO, (b) P-RGO

In the P-RGO process, the loss of several functional groups of oxygen-containing GO after the ultrasonication process must be considered. The formation of P-RGO will cause the loss of the transmittance band with a wavenumber of about $984 \mathrm{~cm}^{-1}$, and the wavenumbers will be around $1628 \mathrm{~cm}^{-1}$, which is the wavelength of the functional group of aromatic carbon $(\mathrm{C}=\mathrm{C})$. This shows that there is a double bond reaction, 
namely the $\mathrm{C}=\mathrm{C}$ aromatic bond, indicating the formation of P-RGO. In addition, the formation of a weak $\mathrm{OH}$ (hydroxyl) bond at a wavenumber of $3450.51 \mathrm{~cm}^{-1}$, where on GO the $\mathrm{OH}$ (hydroxyl) functional group is present giving a strong bond. The weakness or strength of the bond is indicated by the depth of the valley produced in the FTIR spectrum. As expected, the results of spectral and FTIR analysis of P-RGO based on coconut shell waste have many similarities with RGO from the literature or with RGO synthesized from pure (commercial) graphite [21].

Table 1 - Bond types (functional groups) and wavenumbers of RGO and P-RGO materials

\begin{tabular}{|c|c|c|c|c|}
\hline Peak & $\begin{array}{c}\text { Wavenumber } \\
\text { RGO }\left(\mathrm{cm}^{-1}\right)\end{array}$ & $\begin{array}{c}\text { Bond } \\
\text { type }\end{array}$ & $\begin{array}{c}\text { Wavenumber } \\
\text { P-RGO }\left(\mathrm{cm}^{-1}\right)\end{array}$ & $\begin{array}{c}\text { Bond } \\
\text { type }\end{array}$ \\
\hline 1 & 3449.39 & $-\mathrm{OH}$ & 3450.51 & $-\mathrm{OH}$ \\
\hline 2 & 1627.63 & $-\mathrm{C}=\mathrm{C}$ & 1628.02 & $-\mathrm{C}=\mathrm{C}$ \\
\hline 3 & 1216.58 & $-\mathrm{C}-\mathrm{O}$ & 1229.14 & $-\mathrm{C}-\mathrm{O}$ \\
\hline 4 & 1045.88 & $-\mathrm{C}-\mathrm{O}$ & - & - \\
\hline
\end{tabular}

UV-Visible characterization was used to determine the optical properties of RGO and P-RGO based on coconut shell waste. Fig. 6 shows the absorbance spectrum of coconut shell waste based RGO and P-RGO in the 200-800 $\mathrm{nm}$ wavelength range, namely the value of the light intensity or energy absorbed by particles in the colloidal solution of the sample. UV-visible spectral results were then analyzed using the Tauc plot method to determine the band gap energy $\left(E_{g}\right)$ of RGO based on coconut shell waste [22]. The equation that determines the band gap energy:

$$
(\alpha h v)^{1 / n}=A\left(h v-E_{g}\right),
$$

where $\alpha$ is the absorption coefficient, $h v$ is the photon energy, $K$ is an energy-independent constant, and $E_{g}$ is the band gap [23]. The value of $h v$ equal to 1240 is obtained from the Max Planck equation. The value of $\alpha$ of 2.303 is calculated from the absorbance data using the Beer-Lambert law, as shown in Fig. 8. The equation is given below:

$$
\alpha=A \frac{1}{\log (e) L}
$$

where $A$ is the absorbance data, $\log (e)$ is 0.4343 , and $L$ is the cuvette path length $(1 \mathrm{~cm})$. The values of $E_{g}$ are equal to the intercept on the abscissa axis by fitting the Tauc equation $(\alpha h v)^{2} \sim h v$ plots [24].

The results of band gap energy analysis using the Tauc plot method for GO based on coconut shell waste are shown in Fig. 7. As seen, the band gap energies of RGO and P-RGO based on coconut shell waste are $3.50 \mathrm{eV}$ (Fig. 7a) and $4.41 \mathrm{eV}$ (Fig. 7b), respectively. This result indicates that coconut shell waste, initially an insulating material, can become a semiconductor material after synthesizing it in RGO and P-RGO, as well as pure graphite-based RGO and P-RGO. While the insulator has a band gap energy of $\geq 5 \mathrm{eV}$ [25], after being synthesized in RGO and P-RGO, the material is a semiconductor with a band gap energy of $<5 \mathrm{eV}$. It is evident from the analysis that the band gap energy of RGO and P-RGO has potential applications in electronic devices.
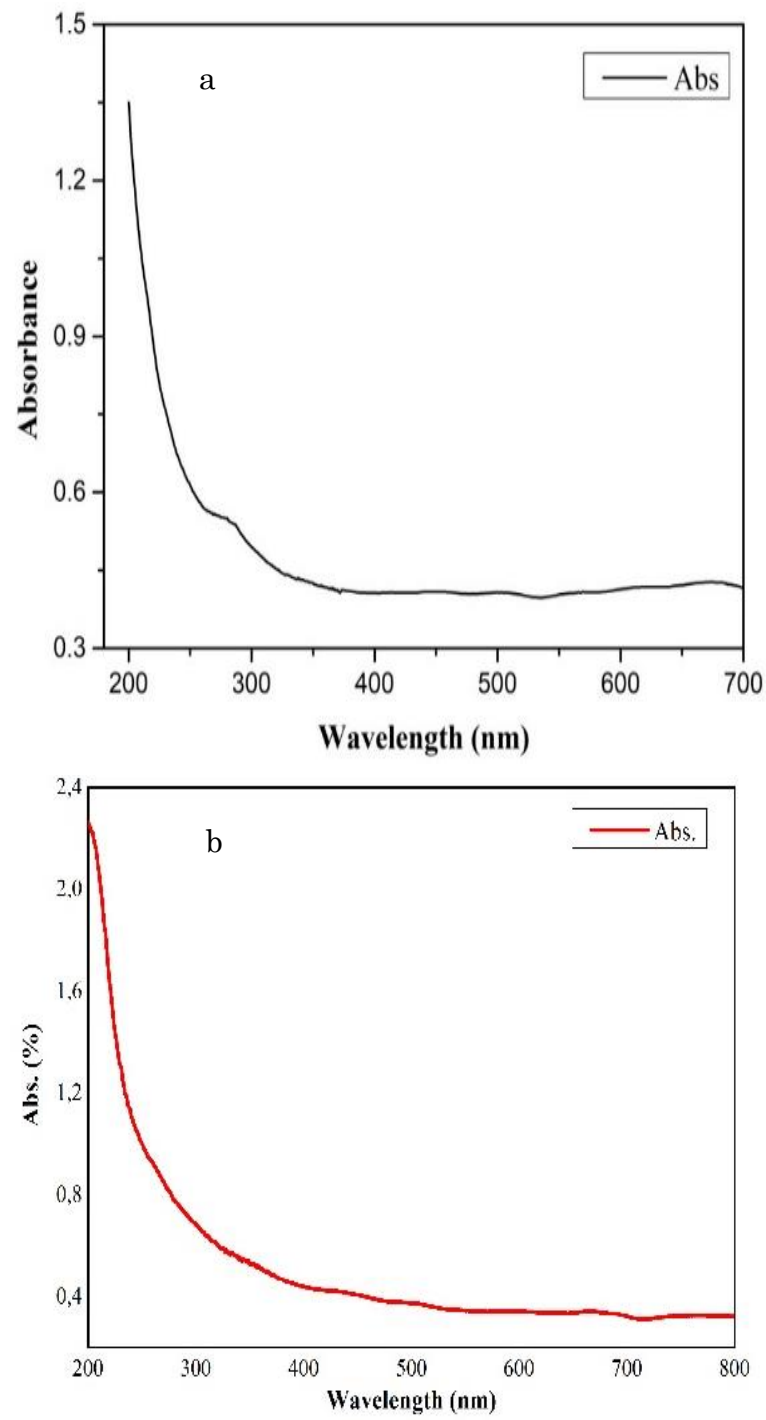

Fig. 6 - UV-Visible spectrum based on coconut shell waste: (a) RGO, (b) P-RGO

\section{CONCLUSIONS}

RGO and P-RGO materials have been successfully synthesized from coconut shell waste. The result of XRD analysis showed that RGO and P-RGO have two dominant peaks. The FTIR spectrum confirmed the presence of various oxygen-containing functional groups such as hydroxyl, aromatic, epoxy, and alkoxy in the RGO structure. Meanwhile, P-RGO showed that the functional groups of the formed compounds are only the hydroxyl, aromatic, and epoxy. Analysis using the Tauc plot method showed that the band gap energy for RGO was $3.50 \mathrm{eV}$, and for P-RGO it was $4.41 \mathrm{eV}$, indicating semiconductor properties. Based on the characterization data obtained, RGO and P-RGO can be used as functional materials. 

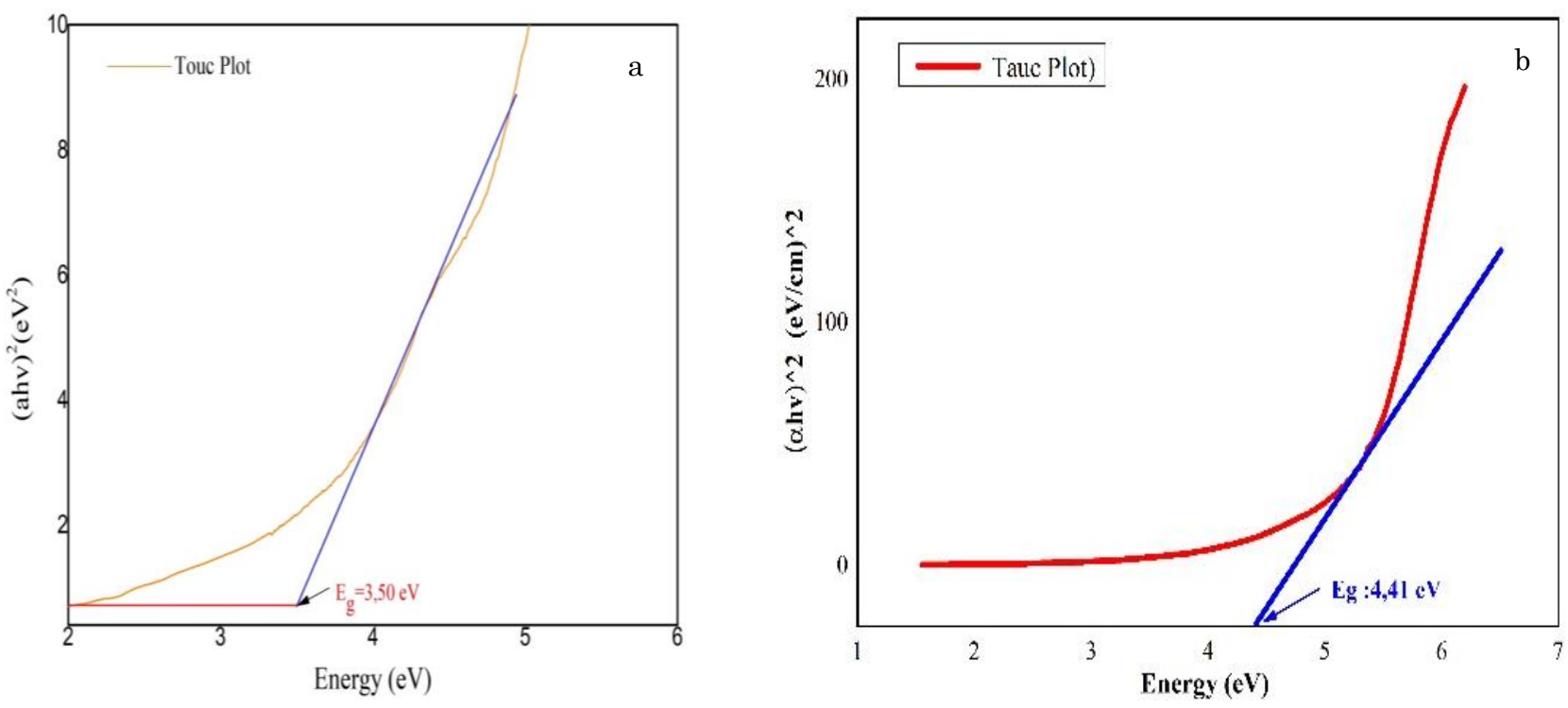

Fig. 7 - Band gap energy value based on coconut shell waste after analysis using the Tauc plot method: (a) RGO, (b) P-RGO

\section{ACKNOWLEDGEMENTS}

This research was funded by the Directorate of resources, Directorate General of Higher Education,

\section{REFERENCES}

1. V. Strauss, K. Marsh, M.D. Kowal, M. El-kady, R.B. Kaner, Adv. Mater. 30, 1704449 (2018).

2. Y. Shen, Z. Qin, S. Hu, L. Yang, X. Xu, L. Ding, Y. Zhang, Carbon 158, 711 (2020)

3. C. Wang, Z.S. Lu, J. Ma, X. Chen, C. Yang, W. Xia, Diam. Relat. Mater. 111, 108176 (2020).

4. R. Kumar, S. Sahoo, E. Joanni, R.K. Singh, W.K. Tan, K.K. Kar, A. Matsud, Prog. Energy Combust. Sci. 75, 100786 (2019).

5. L. Kang, R. Sato, B. Zhang, Y. Takeda, J. Tang, Opt. Mater. (Amst). 110, 110463 (2020).

6. H. Liu, H. Qiu, Chem. Eng. J. 393, 124691 (2020).

7. Y. Wang, Y. Chen, S.D. Lacey, L. Xu, H. Xie, T. Li, V.A. Danner, L. Hu, Mater. Today 21 No 2, 186 (2018).

8. Z. Cui, X. Bai, Ultrason. Sonochem. 70, 105309 (2021).

9. J. Theerthagiri, J. Madhavan, S.J. Lee, M.Y. Choi, M. Ashokkumar, B.G. Pollet, Ultrason. Sonochem. 63, 104960 (2020).

10. D. Balram, K. Lian, N. Sebastian, Ultrason. Sonochem. 58, 104650 (2019).

11. H. Yang, S. Ye, J. Zhou, T. Liang, Front. Chem. 7, 724 (2019).

12. G. Bharath, E. Alhseinat, N. Ponpandian, M.A. Khan, M.R. Siddiqui, F. Ahmed, E.H. Alsharaeh, Sep. Purif. Technol. 188, 206 (2017).

13. M. Rethinasabapathy, S. Kang, S. Jang, Y.S. Huh, Carbon Lett. 22, 1 (2017).
Research and Technology, Ministry of Education, Culture, Research and Technology, Republic of Indonesia, under research scheme of Penelitian Dasar Unggulan Perguruan Tinggi (PDUPT) fiscal year of 2021.
14. M. Pan, J. Wang, M. Hua, G. Gao, X. Wang, J. Wei, Carbon 154, 384 (2019).

15. M. Sethi, H. Bantawal, U.S. Shenoy, D.K. Bhat, J. Alloy. Compd. 799, 256 (2019).

16. T.S. Qureshi, D.K. Panesar, Constr. Build. Mater. 206, 71 (2019).

17. Y. Jia, L. Zhang, A. Du, G. Gao, J. Chen, X. Yan, C.L. Brown, X. Yao, Adv. Mater. 28, 9532 (2016).

18. E.H. Sujiono, Zurnansyah, D. Zabrian, M.Y. Dahlan, B.D. Amin, Samnur, J. Agus, Heliyon 6 No 8, e04568 (2020).

19. W. Peng, S. Liu, H. Sun, Y. Yao, L. Zhic, S. Wang, J. Mater. Chem. A 1 No 19, 5854 (2013).

20. B. Gupta, N. Kumar, K. Panda, V. Kanan, S. Joshi, I. VisolyFisher, Sci. Rep. 7, 45030 (2017).

21. H. Yang, S. Ye, J. Zhou, T. Liang, Front. Chem. 7, 274 (2019).

22. R.A. Rochman, S. Wahyuningsih, A.H. Ramelan, IOP Conf. Ser.: Mater. Sci. Eng. 509, 012119 (2019).

23. A.P. Sergio, X. Xu, A.M. Ulises, Carbon 146, 491 (2019).

24. S. Guo, K. Hayakawa, C. Link, phys. status solidi 60 No 8, 1789 (2015).

25. F. Zheng, W.L. Xu, H.D. Jin, X.T. Hao, K.P. Ghiggino, RSC Adv. 5 No 109, 89515 (2015).

26. P. Phukan, R. Narzary, P.P. Sahu, Mater. Sci. Semicond. Process. 104, 104670 (2019).

\title{
Порівняльне дослідження та характеристики відновленого оксиду графену (RGO) та пористого відновленого оксиду графену (P-RGO) на основі відходів шкаралупи кокосового горіха
}

\author{
Samnur ${ }^{1}$, N. Azizah², N. Fahira², Zurnansyah ${ }^{2}$, Dirfan Zabrian², V. Zharvan², E.H. Sujiono²
}

${ }^{1}$ Department of Mechanical Engineering, Universitas Negeri Makassar, 90224 Makassar, Indonesia ${ }^{2}$ Laboratory of Materials Physics, Department of Physics, Universitas Negeri Makassar, 90224 Makassar, Indonesia 
Методом ексфоліації синтезовано зразки RGO та P-RGO на основі відходів шкаралупи кокосового горіха. Ці зразки були охарактеризовані за допомогою XRD, FTIR та УФ-видимої спектроскопії для отримання їх кристалічної структури, функціональної групи та оптичних властивостей. Результати XRD зразків RGO та P-RGO показують два піки, подібні до піків RGO та P-RGO, синтезованих із чистого (комерційного) графіту. Характеризація FTIR зразка RGO показуе гідроксильну $(-\mathrm{OH})$, ароматичну $(-\mathrm{C}=\mathrm{C})$, епоксидну $(\mathrm{C}-\mathrm{O})$ та алкоксильну $(\mathrm{C}-\mathrm{O})$ фоункціональні групи при 3449,$39 ; 1627,63$; 1216,58 і 1045,88 см $^{-1}$ відповідно. Водночас у зразку P-RGO утворені гідроксильна $(-\mathrm{OH})$, ароматична $(\mathrm{C}=\mathrm{C})$ та епоксидна (CO) функціональні групи при 3450,$51 ; 1628,02$ та $1229,14 \mathrm{~cm}^{-1}$ відповідно. Крім того, результати УФ-видимої спектроскопії для RGO i P-RGO показують достатню оптичну продуктивність. Значення енергії забороненої зони зразків, отриманих за допомогою графіка Таука, становлять 3,50 еВ і 4,41 еВ, що вказуе на властивості напівпровідника.

Ключові слова: RGO, P-RGO, GO, Графіт, Відходи шкаралупи кокосового горіха, Енергія забороненої зони. 